\title{
THE EFFECT OF DEPOSITION TIME AND SULFURIZATION TEMPERATURE ON THE OPTICAL AND STRUCTURAL PROPERTIES OF IRON SULFIDE THIN FILMS DEPOSITED FROM ACIDIC CHEMICAL BATHS
}

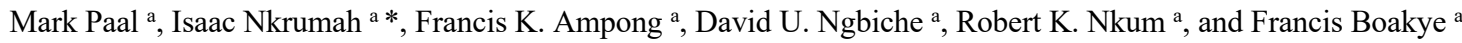 \\ ${ }^{a}$ Dept. of Physics, Kwame Nkrumah University of Science and Technology, Kumasi, Ghana \\ (paalmark@ymail.com; inkrumah.sci@knust.edu.gh; fkampong.cos@knust.edu.gh; davidngbiche@gmail.com; \\ rknkum.cos@knust.edu.gh; fboakye.sci@knust.edu.gh)
}

\begin{abstract}
:
Pyrite phase $\mathrm{FeS}_{2}$ thin films have been grown by a two-stage process of chemical bath deposition followed by sulfurization. Thiourea and thioacetamide were used as sulfur precursors in separate baths. The deposition time was controlled for 1, 2, and 3 hours respectively. The as-deposited films were sulfurized at temperatures of $250{ }^{\circ} \mathrm{C}$ and $500{ }^{\circ} \mathrm{C}$ to form the pyrite phase. The effect of deposition time and sulfurization temperature on the structure, morphology and optical properties of the iron pyrite films obtained from the two separate baths were studied and compared. X-ray diffraction analyses established the formation of the pyrite phase in all the films after sulfurization, in addition to iron (II) oxide hydrate as impurities. All films showed further improvement in pyrite formation, crystallinity as well as an increase in crystallite size after sulfurizing at $500{ }^{\circ} \mathrm{C}$. EDAX and SEM microscopy showed that the iron pyrite films produced from the bath containing thiourea, had better crystallinity and a higher iron content. The optical band gap of the iron pyrite films obtained with thiourea, was $2.1,1.9$ and $1.6 \mathrm{eV}$ for the various deposition times. With thioacetamide, the band gap was $1.4 \mathrm{eV}$, for the deposition time of 3 hours.
\end{abstract}

KEYWORDS: Chemical bath deposition, Iron pyrite thin films, Sulfurization, Photovoltaic materials.

\section{INTRODUCTION}

Iron pyrite cubic phase is a remarkable semiconductor with estimated reserves of $10^{12} \mathrm{~kg}$ on the earth's surface (Zhao et al., 2017). It has a bandgap of $0.95 \mathrm{eV}$, absorption coefficient $(\alpha)$ of $5 \times 10^{5} \mathrm{~cm}^{-1}$ for wavelengths, $\lambda=700 \mathrm{~nm}$ (Banjara et al., 2018) and adequate minority carrier diffusion length of 100 - 1000 nm (Cabán-Acevedo et al., 2012; Liu et al., 2014). These properties coupled with its low extraction costs and abundance gives pyrite the potential to be a competitive photovoltaic material when compared to many other candidates (Wadia et al., 2009). A pyrite cell with only $4 \%$ efficiency could be as cost effective as a similar single crystalline silicon solar cell of $20 \%$ efficiency (Bi et al., 2011). Despite these promising characteristics and diverse fabrication techniques, there are no known pyrite-based photovoltaic (PV) devices currently in existence. This could be attributed to its low PV conversion efficiency of $2.8 \%$ (Richardson et al., 2013). This low performance could be attributed to high density of surface defects. In addition, a low open-circuit voltage of around 0.2 $\mathrm{mV}$, could be attributed to the presence of phase impurities (Moon et al., 2018). Orthorhombic marcasite $\mathrm{FeS}_{2}$ and hexagonal troilite $\mathrm{FeS}$ are common iron sulfur phases, which may form as impurities. They have much smaller band gaps ( $0.34 \mathrm{eV}$ for marcasite and $0.04 \mathrm{eV}$ for troilite), thus, even trace amounts of these phases, would explain the low open circuit voltage observed (Wadia et al., 2009).

Several synthesis techniques such as; sulfurization of electrodeposited films (Wang et al., 2013), hydrothermal method (Liu et al., 2014), spray pyrolysis (Al Khateeb \& Sparks, 2019) and metal-organic chemical vapor deposition
(MOCVD) (Clayton et al., 2011), have been developed to deposit iron pyrite thin films.

Among these techniques, the chemical bath deposition (CBD) is a very common deposition method with respect to economic considerations (Anuar et al., 2012).

The synthesis of nanocrystalline metal chalcogenide and metal oxide thin films by chemical bath deposition (CBD) method is currently attracting considerable attention as it is relatively inexpensive, simple and convenient for large area deposition (Pawar et al., 2011). CBD is an important deposition technique for thin films of compound materials like chalcogenides (Hodes, 2002).

The characteristics of chemical bath deposited thin films are strongly influenced by the growth conditions. Variations in key parameters such as; reactant concentrations, $\mathrm{pH}$, deposition temperature and time, etc. can cause significant changes in the microstructure characteristics and hence observed physical properties (Hone et al., 2014).

Different investigations on the chemical bath deposition of iron pyrite thin films have been reported by several independent research groups, using different deposition parameters and experimental conditions.

Prabukanthan et al. (2010) processed CBD deposited FeS thin films in a sulfur and nitrogen rich atmosphere to form the pyrite phase of $\mathrm{FeS}_{2}$. The authors concluded that an optimum sulfurization temperature between $400{ }^{\circ} \mathrm{C}$ and $500{ }^{\circ} \mathrm{C}$ for a duration of one hour, yielded the iron pyrite cubic phase. They also reported that the optical band gaps are controlled by the disorder in the films network regardless of the sulfurization temperature and time duration. Saeed Akhtar et al. (2015) used the CBD technique without any post deposition heat treatment.

* Corresponding author

This is an open access under a CC BY-NC-SA 4.0 license (https://creativecommons.org/licenses/by-nc-sa/4.0/) 
They reported the formation of Monophasic (mackinawite) FeS thin films. Studies on the thermal treatment of chemical bath deposited iron pyrite thin films were reported by MazónMontijo et al. (2013). The authors sulfurized the as-deposited films at $400{ }^{\circ} \mathrm{C}$ with the duration varied between 3 to 10 hours. They concluded that prolonged heating did not improve the crystallinity of the films, rather, heat treatment lasting for 3 hours with $15 \mathrm{mg}$ of elemental sulfur was sufficient to convert $\mathrm{a}-\mathrm{FeO} / \mathrm{S}$ to polycrystalline pyrite thin films. Aluri et al. (2015) also reported the growth of polycrystalline and single phase $\mathrm{FeS}_{2}$ films as a potential absorber layer in solar cells. They recommended a bath temperature of $70{ }^{\circ} \mathrm{C}$ for achieving a pure pyrite phase.

In this study, pyrite phase $\mathrm{FeS}_{2}$ thin films have been synthesized from two separate acidic chemical baths, one with thiourea as the sulfur precursor and the other with thioacetamide followed by sulfurization to obtain the pyrite phase. The effect of deposition time and sulfurization temperature on the structure, morphology and optical properties of the iron pyrite films obtained from the two separate baths, are studied and compared. To the best of our knowledge, the reactants used in this work together with their concentrations, are being used for the first time under the deposition conditions reported in this study.

\section{MATERIALS AND METHODS}

The chemicals used were iron sulfate heptahydrate $\left(\mathrm{FeSO}_{4} \cdot 7 \mathrm{H}_{2} \mathrm{O}\right)$ as the iron source, thiourea $\left(\mathrm{CS}\left(\mathrm{NH}_{2}\right)_{2}\right)$ both from BDH laboratories and thioacetamide $\left(\mathrm{CH}_{3} \mathrm{CSNH}_{3}\right)$ from Merck laboratory. Sodium hydroxide $(\mathrm{NaOH})$ from $\mathrm{BDH}$ laboratories to adjust the $\mathrm{pH}$ and ethylene-diamine-tetra-acetic acid di-sodium salt ( $\mathrm{Na}_{2}$ EDTA) from Fizmerk laboratories was used as a complexing agent.

Thiourea and thioacetamide are sulfur precursors which are normally used for chemical bath deposition of compound materials like chalcogenides. Thiourea is the most commonly used sulfur precursor. Thioacetamide can be hydrolyzed over a wide range of $\mathrm{pH}$ and is often used for CBD in acidic baths (Hodes, 2002).

Prior to deposition, the microscope glass slides were degreased in nitric acid and subsequently kept in ethanol for about 30 minutes, then ultrasonically cleaned with distilled water and dried under ambient condition (Hone et al., 2015).

In a typical reaction mixture, $20 \mathrm{ml}$ of $0.3 \mathrm{M}$ iron sulfate, $4 \mathrm{ml}$ of $0.1 \mathrm{M}$ sodium EDTA and $20 \mathrm{ml}$ of $0.3 \mathrm{M}$ thiourea were mixed in a $100 \mathrm{ml}$ beaker. The $\mathrm{pH}$ of the reactant mixture was about 1 and this was adjusted to 2.5 by the addition of $3 \mathrm{ml}$ of $0.1 \mathrm{M}$ sodium hydroxide. The solution was then placed in a water bath kept at a temperature of $80{ }^{\circ} \mathrm{C}$ for deposition. Chemically cleaned glass slides were fastened to a holder and placed vertically in the beaker. The mixture was stirred continuously for uniform film deposition. The deposition time was controlled for 1, 2, and 3 hours respectively. After deposition, the substrates were taken out and washed with distilled water to remove any non-adherent particulate matter and allowed to dry under ambient conditions.

This same process was repeated in a second bath containing thioacetamide as the sulfur precursor.

It was observed that when thiourea was used as the sulfur precursor, films were obtained for each deposition time, however, with thioacetamide as the sulfur precursor, substantial film growth occurred only at a deposition time of 3 hours.

All the as-deposited films appeared brownish to the naked eye, however the films deposited from baths containing thioacetamide, were of a much darker color as shown in Figures 1 and 2.

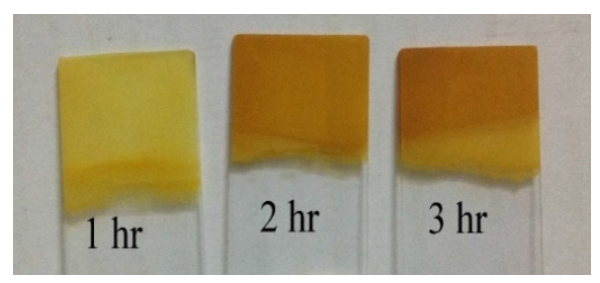

Figure 1. Films deposited with a time of 1 hour, 2 hours and 3 hours respectively, from baths containing thiourea as the sulfur precursor.

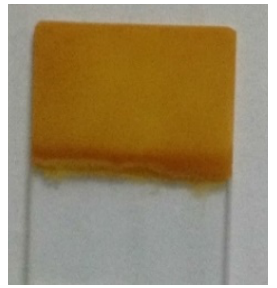

Figure 2. Film deposited with a time of 3 hours from the bath containing thioacetamide as the sulfur precursor.

\subsection{Sulfurization}

The pyrite phase is obtained by treating pre-deposited films thermally in a sulfur rich atmosphere, this process is called sulfurization. Sulfurization plays an important role in the crystalline formation as it fills sulfur vacancies and improves crystallinity due to the heat treatment. It also removes defects and other phases of $\mathrm{FeS}_{2}$ to obtain pure pyrite.

In this work, the sulfurization process was carried out using the technique described by Botchway et al. (2019) in Figure 3.

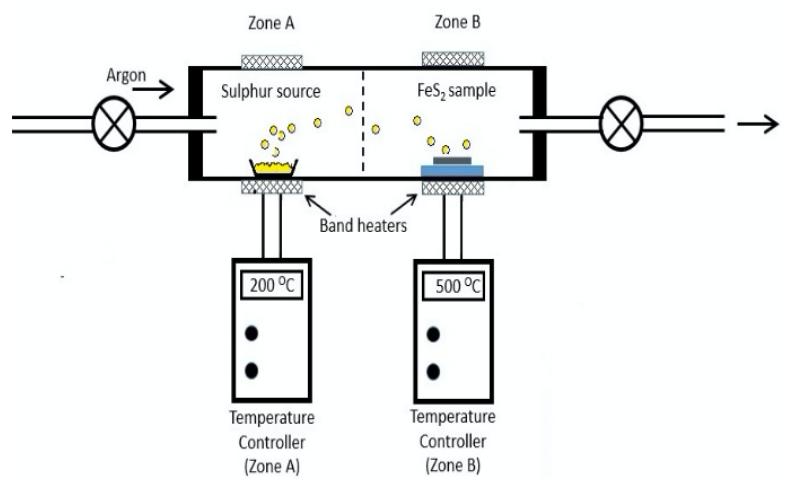

Figure 3. Schematic illustration of the two-heating-zone borosilicate-tube furnace (Botchway et al., 2019).

A borosilicate tube furnace with two heating zones was flushed with argon for 10 minutes to get rid of any oxygen. $0.5 \mathrm{~g}$ of elemental sulfur powder was placed in a ceramic boat and kept at one end, with the iron sulfide sample placed at the other end. The temperature at the sulfur heating zone was kept at $200{ }^{\circ} \mathrm{C}$, whilst temperatures of $250{ }^{\circ} \mathrm{C}$ and $500{ }^{\circ} \mathrm{C}$ were used for the sample heating zone. An argon flux carried the sulfur vapor towards the sample placed at the other end of the tube. All the samples were sulfurized for an hour, after which the furnace was switched off and allowed to cool under the flow of argon.

\subsection{Film Thickness}

The average thickness of the films was determined after sulfurization using the gravimetric method. For films deposited with thiourea as the sulfur source, the thickness was $100 \mathrm{~nm}$, $150 \mathrm{~nm}$ and $176 \mathrm{~nm}$ for deposition times of 1, 2 and 3 hours. With thioacetamide, the thickness was $183 \mathrm{~nm}$, for films deposited at 3 hours. 


\subsection{Thin film characterization}

The crystal structure of the as-deposited and sulfurized $\mathrm{FeS}_{2}$ thin films were analyzed by a PANalytical Empyrean X-ray diffractometer with $\mathrm{Cu}-\mathrm{k} \alpha$ radiation $\left(\lambda_{\alpha 1}=1.5406 \dot{A}\right)$. The elemental composition and surface morphology of the samples were determined by energy dispersive X-ray analysis (EDX) attached to a high resolution JEOL JSM-7600F scanning electron microscope (SEM). Optical absorption measurements were taken with the UV-Vis spectrophotometer (Cecil CE 7500 series) within the wavelength range of $190-1100 \mathrm{~nm}$.

\section{RESULTS AND DISCUSSION}

\subsection{Structural analysis}

Figure 4 shows the XRD pattern for $\mathrm{FeS}_{2}$ films at various stages of the synthesis processes. These films were grown with a deposition time of 1 hour, from baths containing thiourea as the sulfur precursor.

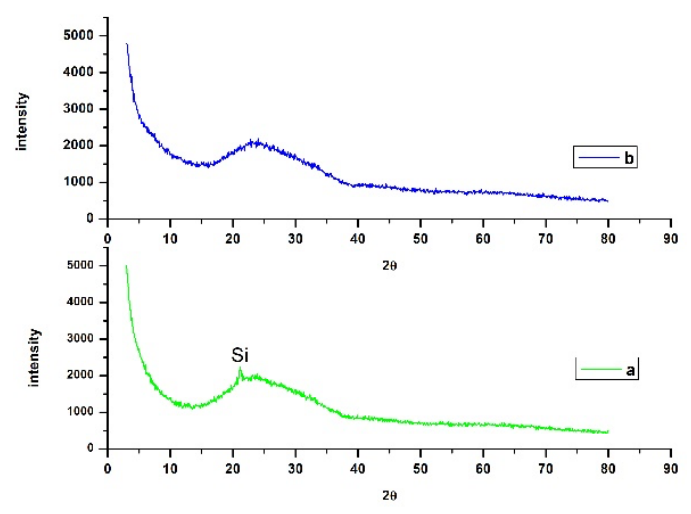

Figure 4. Films grown with a deposition time of 1 hour, from baths containing thiourea. (a) as-deposited film, (b) film sulfurized at $250^{\circ} \mathrm{C}$

From Figure 4, it can be observed that the as-deposited film has a single low intensity peak indexed to silicon oxide [JCPDS 01-077-8628], which could emanate from the substrate used. There were no discernable peaks indexed to iron sulfide even after sulfurizing at $250{ }^{\circ} \mathrm{C}$.

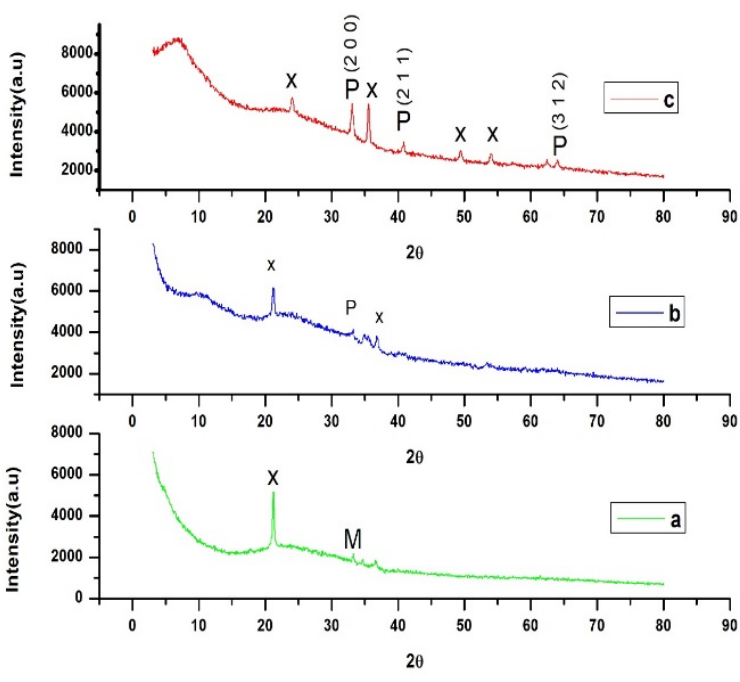

Figure 5. Films grown with a deposition time of 2 hours, from baths containing thiourea. (a) as-deposited film, (b) film sulfurized at $250^{\circ} \mathrm{C}$ and (c) film sulfurized at $500^{\circ} \mathrm{C}$.

The diffraction pattern for the as-deposited film, Figure 5(a), shows peaks which were matched to Marcarsite, labeled $\mathrm{M}$ and iron oxide hydrate $\left(\mathrm{Fe}_{2} \mathrm{O}_{3} \cdot \mathrm{H}_{2} \mathrm{O}\right)$ labeled X [JCPDS: 00-0030799 and 00-001-0401]. There were no discernable peaks indexed to the pyrite phase at this stage. After the thin films were sulfurized at $250{ }^{\circ} \mathrm{C}$ (Figure $5(\mathrm{~b})$ ), there was a decrease in intensity of the peaks $\mathrm{X}$ and $\mathrm{M}$, and the appearance of a low intensity peak indexed to the (200) plane of $\mathrm{FeS}_{2}$ pyrite phase labeled as, P, [JCPDS: 98-001-0422]. After sulfurization at 500 ${ }^{\circ} \mathrm{C}$ (Figure 5(c)), the impurity peak, $\mathrm{X}$, further decreased in intensity and the number of peaks indexed to the pyrite phase, increased to include reflections from the (211) and (312) planes of the pyrite phase. This suggests that there was further improvement in pyrite formation at the sulfurization temperature of $500{ }^{\circ} \mathrm{C}$. Figure 5(c) also shows an increase in intensity of the peaks corresponding to the pyrite phase, suggesting an improvement in crystallinity of the films

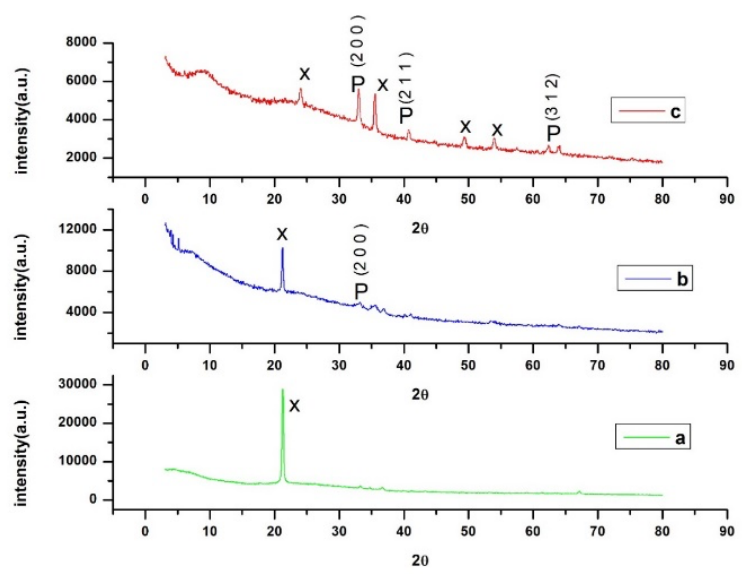

Figure 6. Films grown with a deposition time of 3 hours, from baths containing thiourea (a) as-deposited film, (b) film sulfurized at $250^{\circ} \mathrm{C}$ and (c) film sulfurized at $500^{\circ} \mathrm{C}$.

The XRD patterns shown in Figure 6, are for the films grown with a deposition time of 3 hours, from baths containing thiourea as the source of sulfur ions. The diffraction patterns are similar to that of Figure 5, where the as-deposited films are composed of mainly iron oxide, labelled X. Sulfurization at $250{ }^{\circ} \mathrm{C}$, shows a decrease in the intensity of $\mathrm{X}$, and the 
appearance of a peak corresponding to reflections from the (200) plane of the cubic pyrite phase at a $2 \theta$ angle of approximately $33^{\circ}$ labeled P, [JCPDS: 98-001-0422]. After sulfurizing at $500^{\circ} \mathrm{C}$ (Figure 6(c)), there was a further decrease in intensity of the impurity peak, $\mathrm{X}$, and the number of peaks contributing to the cubic pyrite phase increased to include reflections from the (211) and (312) planes.

Comparing Figures 5(c) and 6(c), the films obtained with a deposition time of 3 hours, appear to have more intense peaks, suggesting better crystallinity.

Figure 7 shows the XRD pattern of films grown with a deposition time of 3 hours, from baths containing thioacetamide as the source of sulfur ions and sulfurized at 250 ${ }^{\circ} \mathrm{C}$ and $500{ }^{\circ} \mathrm{C}$

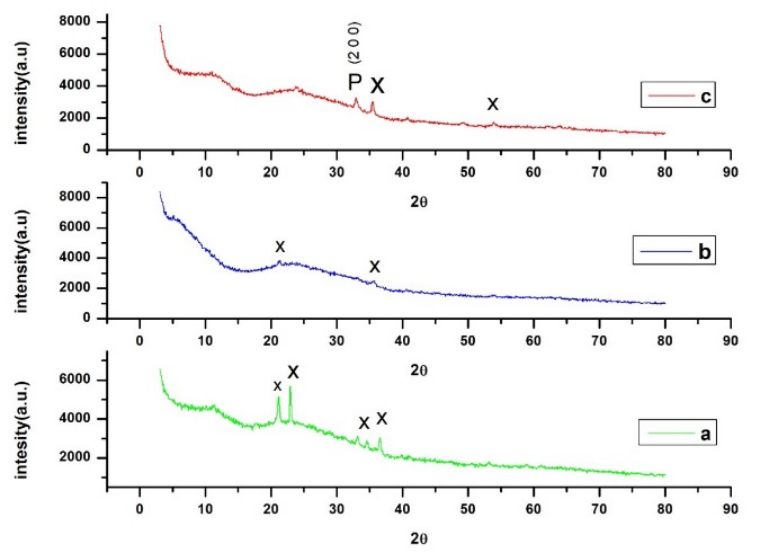

Figure 7. Films grown with a deposition time of 3 hours, from baths containing thioacetamide, (a) as-deposited film, (b) film sulfurized at $250^{\circ} \mathrm{C}$ and (c) film sulfurized at $500^{\circ} \mathrm{C}$

The diffraction pattern shown in Figure 7 suggests that the asdeposited film and the film sulfurized at $250{ }^{\circ} \mathrm{C}$ are composed of mainly iron oxide $\left(\mathrm{Fe}_{3} \mathrm{O}_{4}\right)$. There are no discernible peaks indexed to the pyrite phase after sulfurizing at $250{ }^{\circ} \mathrm{C}$. The presence of a low intensity peak indexed to the (200) plane of the pyrite phase can be observed after sulfurizing at $500{ }^{\circ} \mathrm{C}$. A few impurity peaks were also observed at this stage.

The relatively fewer number of peaks observed in Figure 7(c) suggests that the pyrite phase obtained from baths containing thioacetamide have poor crystallinity

Structural properties in Figure 4(a-b), 5(a-c), 6(a-c) and 7(a-c) showed that mixed phase of iron (II) sulfide and iron (II) oxide hydrate are present. It is worth mentioning that there is a possibility that the iron oxide impurities observed in the films after sulfurization could be as a result of self-oxidation of the films during storage prior to the XRD analyses.

3.1.1 Average crystallite size: Calculation of the average grain size was done using the Scherrer's formula (Muniz et al., 2016) which is given as;

$$
D=\frac{K \lambda}{\beta \cos \theta}
$$

Where $\mathrm{D}$ is the crystallite size, $\lambda$ is the $\mathrm{X}$-ray wavelength, $\beta$ full width at half maximum (FWHM) or integral breadth, $\theta$ is the Bragg angle and $\mathrm{K}$ is a constant

The parameters, $\beta$ and $\theta$, were calculated from the peaks indexed to the (200) plane which is the preferred orientation of the pyrite phase.

Table 1 shows the variation in the average grain size with sulfurization temperature. It can be seen from this table that the grain size significantly increased from $250{ }^{\circ} \mathrm{C}$ to $500{ }^{\circ} \mathrm{C}$. This is particularly noticeable with films deposited from baths containing thiourea as the sulfur precursor, where the XRD confirmed the formation of the pyrite phase at both temperatures. According to Hodes (2002) thin films annealed at temperatures above $573 \mathrm{~K}\left(300{ }^{\circ} \mathrm{C}\right)$ usually exhibit a large degree of crystal growth, and this might explain the increase in grain size observed.

Table 1. Variation of the average grain size of the pyrite phase with sulfurization temperature

\begin{tabular}{|c|c|c|c|c|c|}
\hline $\begin{array}{c}\text { Sulfur } \\
\text { Precursor }\end{array}$ & $\begin{array}{c}\text { Deposition time } \\
\text { /hours }\end{array}$ & $\begin{array}{c}\text { Sulfurization } \\
\text { temperature } /{ }^{\circ} \mathrm{C}\end{array}$ & FWHM $(\beta)$ & $2 \theta^{\circ}$ & $\begin{array}{c}\text { Average grain size } \\
\mathrm{D} / \mathrm{nm}\end{array}$ \\
\hline & 2 & 250 & 0.9446 & 33.0558 & 9.1629 \\
Thiourea & 300 & 0.3149 & 33.0437 & 27.4840 \\
& 3 & 250 & 0.9446 & 33.0333 & 9.1623 \\
& 3 & 500 & 0.3149 & 32.9919 & 27.4803 \\
\hline \multirow{2}{*}{ Thioacetamide } & 3 & 500 & 0.3939 & - & - \\
& 250 & 32.9283 & 21.9820 \\
\hline
\end{tabular}

\subsection{Optical analysis}

\subsubsection{Absorbance measurement}

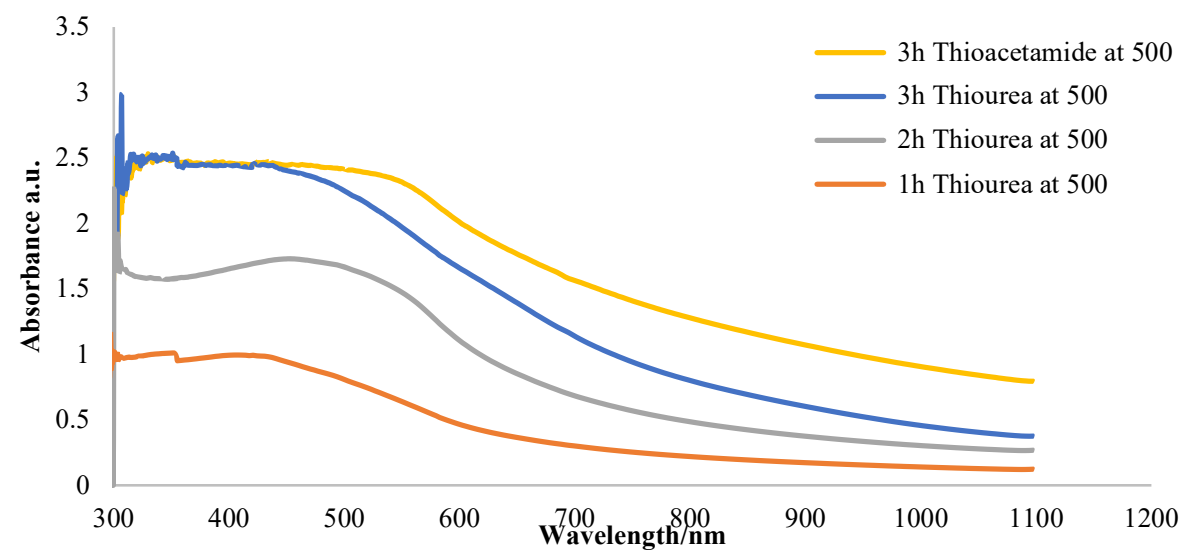

Figure 8. Absorbance spectra of the iron pyrite films obtained after sulfurizing at $500{ }^{\circ} \mathrm{C}$ for deposition times of 1,2 and 3 hours using thiourea as the sulfur precursor and 3 hours using thioacetamide as the sulfur precursor. 
Figure 8 compares the optical absorbance spectra of the pyrite phase of $\mathrm{FeS}_{2}$ thin films obtained from the two different chemical baths and sulfurized at $500{ }^{\circ} \mathrm{C}$. It should be recalled that the XRD analysis confirmed the formation of the pyrite phase in all films irrespective of the sulfur precursor after sulfurizing at $500{ }^{\circ} \mathrm{C}$. Further observations from Figure 8, shows generally that the absorbance increased with increasing deposition time with a corresponding shift in fundamental absorption edge towards longer wavelength, indicating a decrease in band gap. The increase in absorbance can be attributed to a higher yield in $\mathrm{FeS}_{2}$ resulting in an increase in the thickness as the deposition time increased from 1 hour to 3 hours. It has been reported that the thickness of thin solid films synthesized by chemical bath techniques, in which the film formation and kinetics take place by ion-by-ion condensation has a linear relationship with deposition time (Ezema, 2005). The films exhibit a strong absorption edge around $350-500$ nm.

Further observation of Figure 8 shows that the film deposited from the bath containing thioacetamide appears to have a higher absorbance, with the fundamental absorption edge slightly red shifted. This difference could be due to defect states in the deposited thin film or poor crystallinity of the film.

\subsubsection{Determination of optical band gap}

The optical band gap of the film was evaluated from mathematical treatment of data obtained from optical absorbance versus wavelength, with the Stern relationship (Hone et al., 2015) of near-edge absorption which is given as

$$
A=\frac{\left[k\left(h v-E_{g}\right)\right]^{n / 2}}{h v}
$$

where $v$ is the frequency, $h$ is the Planck's constant, $K$ is a constant while $n$ carries the value of either 1 for direct transition or 4 for indirect transition. $\mathrm{n}=1$. Figure 9 shows $(A h v)^{2}$ as a function of $h v$

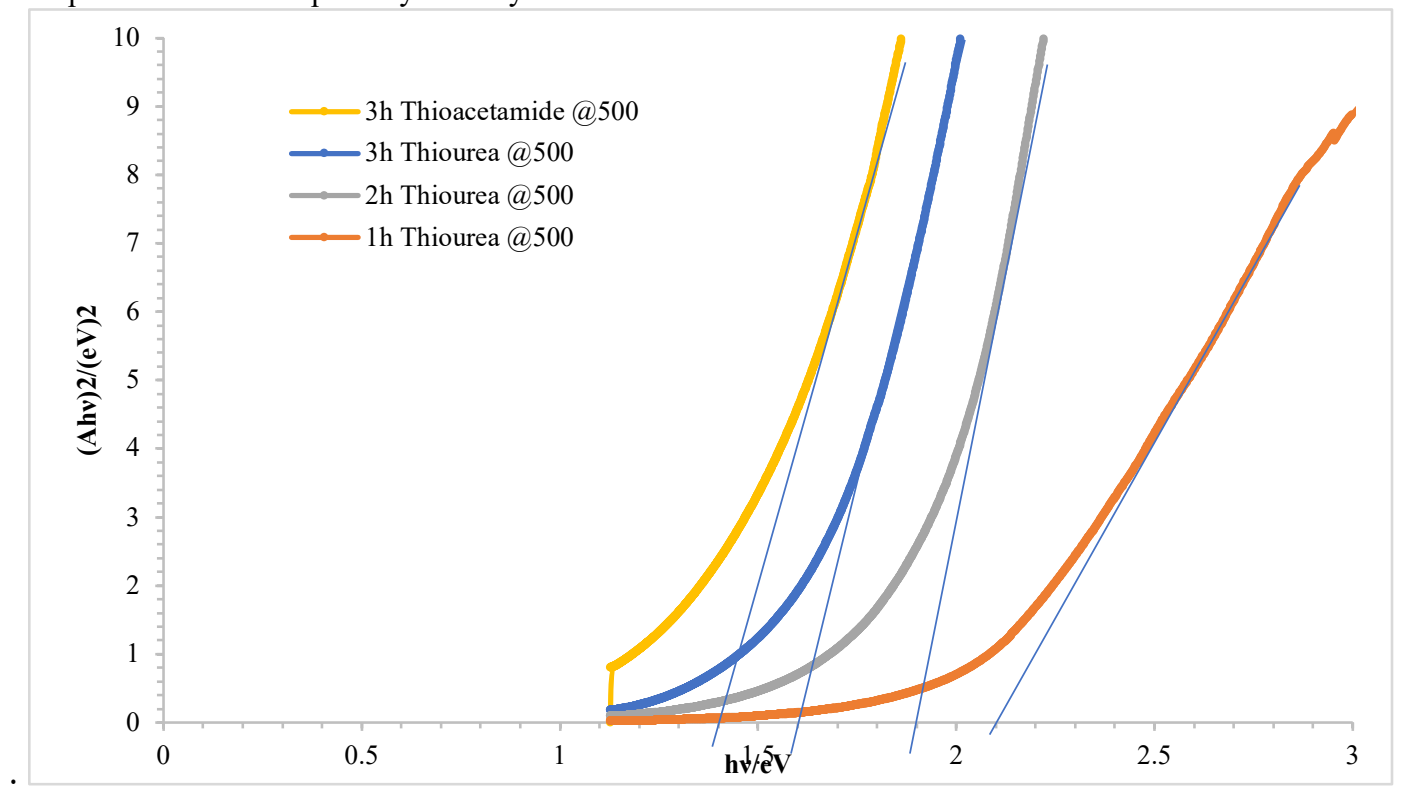

Figure 9. Comparing the optical band gap of the iron pyrite films obtained after sulfurizing at $500{ }^{\circ} \mathrm{C}$ for the various deposition times and different sulfur precursors.

The energy band gap is obtained by plotting a line of best fit to the linear portion of the graph and extrapolating it to the point where it intersects the $h v$ axis as shown in Figure 9. The linear nature of the graph at high $h v$ indicates the presence of a direct transition. From Figure 9, the estimated band gap of the pyrite phase $\mathrm{FeS}_{2}$ obtained after sulfurizing the films at $500{ }^{\circ} \mathrm{C}$, for films deposited from baths containing thiourea as the sulfur source, was found to be 2.1, 1.9 and $1.6 \mathrm{eV}$ for deposition times of 1,2 and 3 hours respectively. For film obtained from the bath using thioacetamide as the sulfur source the band gap of the pyrite phase was $1.4 \mathrm{eV}$.

The value of energy band gap shows high marginal increase (i.e between $2.1 \mathrm{eV}$ to $1.6 \mathrm{eV}$ ) compared to the energy band gap of $0.95 \mathrm{eV}$ for iron (II) sulfide as reported in the literature. This value of energy band gap suggests the presence of iron oxide $(1.95 \mathrm{eV}-2.35 \mathrm{eV})$

It is worth noting that semiconductors with an optical band gap within the range of $1-1.5 \mathrm{eV}$ are suitable for achieving high energy conversion efficiency (about $30 \%$ ) when used as an absorber material in solar cell applications (Ngbiche et al., 2019).

\subsection{Morphology and elemental analysis}

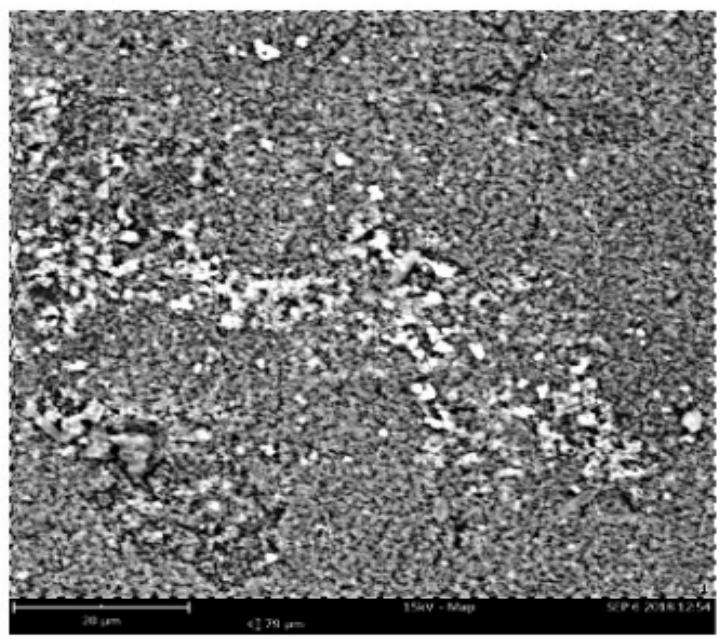

Figure 10. SEM micrograph of iron pyrite $\mathrm{FeS}_{2}$ thin film deposited from chemical bath containing thiourea, deposition time of 3 hours and sulfurized at $500^{\circ} \mathrm{C}$. 


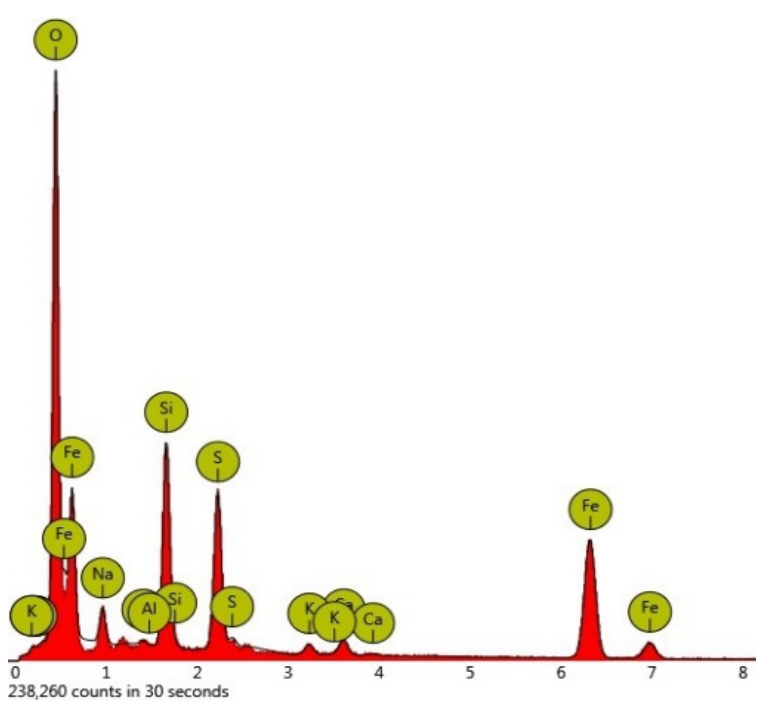

Figure 11. EDAX spectrum of iron pyrite $\mathrm{FeS}_{2}$ thin film deposited from chemical bath containing thiourea, deposition time of 3 hours and sulfurized at $500^{\circ} \mathrm{C}$.

Table 2. Table showing percentage of atomic elements in the film grown with a deposition time of 3 hours, from baths containing thiourea and sulfurized at $500{ }^{\circ} \mathrm{C}$

\begin{tabular}{|c|c|c|c|c|}
\hline $\begin{array}{c}\text { Element } \\
\text { Symbol }\end{array}$ & $\begin{array}{c}\text { Atomic } \\
\text { Conc. }\end{array}$ & $\begin{array}{c}\text { Weight } \\
\text { Conc. }\end{array}$ & $\begin{array}{c}\text { Oxide } \\
\text { Symbol }\end{array}$ & $\begin{array}{c}\text { Stoich. } \\
\text { wt Conc. }\end{array}$ \\
\hline $\mathrm{O}$ & 63.28 & 39.87 & & \\
\hline $\mathrm{Fe}$ & 16.84 & 37.04 & $\mathrm{Fe}$ & 61.60 \\
\hline $\mathrm{Si}$ & 8.55 & 9.46 & $\mathrm{Si}$ & 15.73 \\
\hline $\mathrm{S}$ & 6.88 & 8.69 & $\mathrm{~S}$ & 14.44 \\
\hline $\mathrm{Na}$ & 2.92 & 2.64 & $\mathrm{Na}$ & 4.39 \\
\hline $\mathrm{Ca}$ & 0.81 & 1.28 & $\mathrm{Ca}$ & 2.13 \\
\hline $\mathrm{K}$ & 0.54 & 0.83 & $\mathrm{~K}$ & 1.37 \\
\hline $\mathrm{Al}$ & 0.19 & 0.20 & $\mathrm{Al}$ & 0.33 \\
\hline
\end{tabular}

Figure 10 shows the SEM micrographs of the iron pyrite films obtained from baths containing thiourea, synthesized with a deposition time of 3 hours and sulfurized at $500{ }^{\circ} \mathrm{C}$. The morphology shows compact sharp-edged shaped grains of different sizes and uniformly distributed over the background with very few voids. Figure 11 shows the EDAX spectra which is consistent with the formation of iron sulfide. The presence of silicon and trace quantities of sodium, aluminum, potassium and calcium shown in Table 2, emanate from the substrate used for the deposition and trace amounts of these elements in the salts used.

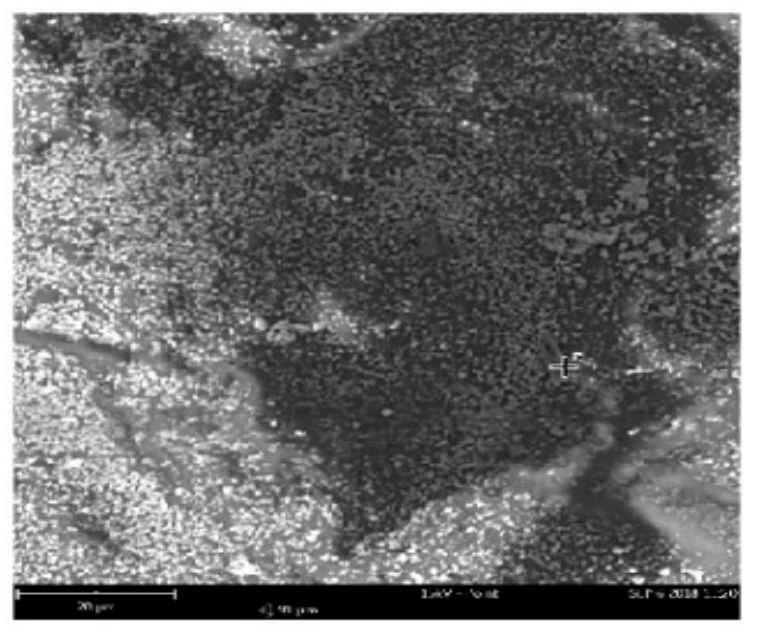

Figure 12. SEM micrograph of iron pyrite $\mathrm{FeS}_{2}$ thin film deposited from chemical bath containing thioacetamide, deposition time of 3 hours and sulfurized at $500{ }^{\circ} \mathrm{C}$

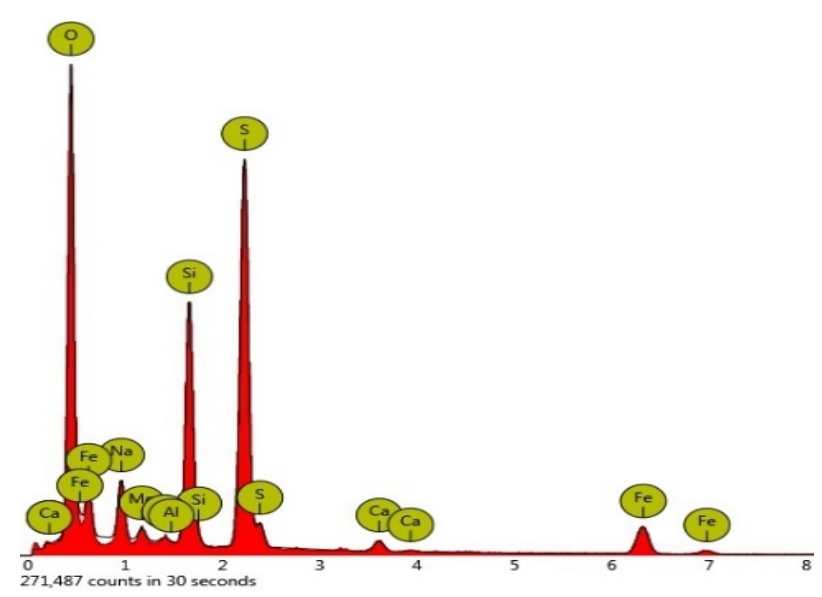

Figure 13. EDAX spectrum of iron pyrite $\mathrm{FeS}_{2}$ thin film deposited from chemical bath containing thioacetamide, deposition time of 3 hours and sulfurized at $500{ }^{\circ} \mathrm{C}$.

Table 3. Table showing percentage of atomic elements in the film grown with a deposition time of 3 hours, from baths containing thioacetamide and sulfurized at $500^{\circ} \mathrm{C}$.

\begin{tabular}{|c|c|c|c|c|}
\hline $\begin{array}{c}\text { Element } \\
\text { Symbol }\end{array}$ & $\begin{array}{c}\text { Atomic } \\
\text { Conc. }\end{array}$ & $\begin{array}{c}\text { Weight } \\
\text { Conc. }\end{array}$ & $\begin{array}{c}\text { Oxide } \\
\text { Symbol }\end{array}$ & $\begin{array}{c}\text { Stoich. } \\
\text { wt Conc. }\end{array}$ \\
\hline $\mathrm{O}$ & 78.06 & 64.77 & & \\
\hline $\mathrm{Si}$ & 12.12 & 17.65 & $\mathrm{Si}$ & 50.10 \\
\hline $\mathrm{Fe}$ & 2.70 & 7.82 & $\mathrm{Fe}$ & 22.18 \\
\hline $\mathrm{Na}$ & 4.56 & 5.44 & $\mathrm{Na}$ & 15.45 \\
\hline $\mathrm{S}$ & 1.22 & 2.03 & $\mathrm{~S}$ & 5.77 \\
\hline $\mathrm{Ca}$ & 0.73 & 1.52 & $\mathrm{Ca}$ & 4.33 \\
\hline $\mathrm{Mg}$ & 0.54 & 0.69 & $\mathrm{Mg}$ & 1.95 \\
\hline $\mathrm{Al}$ & 0.06 & 0.08 & $\mathrm{Al}$ & 0.23 \\
\hline
\end{tabular}

Figure 12 shows the SEM micrographs of the iron pyrite films obtained from baths containing thioacetamide, synthesized with a deposition time of 3 hours and sulfurized at $500{ }^{\circ} \mathrm{C}$., the morphology shows loosely packed granular crystallites with a sandy texture forming an amorphous matrix and having a nonuniform coverage over the entire substrate. This kind of morphology may account for the presence of relatively fewer peaks with low intensity, observed in the diffraction pattern of Figure 7(c).

A comparison of the percentage of atomic elements in Table 2 and 3 shows that the iron pyrite films produced from the bath containing thiourea, had a higher iron content. Percentage of oxygen as shown in both tables confirms the presence of reasonable amount of iron oxide in the films

\section{CONCLUSIONS}

The effect of deposition time and sulfurization temperature on the structural, morphological and optical properties of iron pyrite films deposited from two separate acidic chemical baths, one with thiourea as the sulfur precursor and the other with thioacetamide followed by sulfurization have been studied. The deposition time was controlled for 1,2 , and 3 hours respectively. Sulfurization temperatures of $250{ }^{\circ} \mathrm{C}$ and $500{ }^{\circ} \mathrm{C}$ were used. Results of the characterization techniques established that the deposition time, the sulfurization temperature and choice of sulfur precursor had a significant effect on the properties measured. Structural analysis showed that all the films were not purely pyrite phase of iron (II) sulfide but were composed of mixed phase of iron (II) sulfide and iron (II) oxide hydrate. However, under the deposition conditions used in this work, films deposited from baths containing thiourea as the sulfur precursor, with a deposition time of 3 hours and sulfurized at $500{ }^{\circ} \mathrm{C}$, had much improved properties. 


\section{REFERENCES}

Al Khateeb, S., \& Sparks, T. D. (2019). Spray pyrolysis of conductor- and binder-free porous $\mathrm{FeS}_{2}$ films for high-performance lithium ion batteries. Journal of Materials Science, 54(5), 4089-4104. https://doi.org/10.1007/s10853-018-3055-0

Aluri, V., Reddy, K. T. R., \& Reddy, Y. M. (2015). Polycrystalline and single phase $\mathrm{FeS}_{2}$ films grown by chemical bath deposition. Nanotechnology Reviews, 4(5), 469-472.

Anuar, K., Ho, S. M., Loh, Y. Y., Tan, W. T., \& Saravanan, N. (2012). Complexing Agent Effect on the Properties of Iron Sulphide Thin Films. Canadian Journal of Pure and Appllied Sciences., 6(1), 1863-1867.

Banjara, D., Malozovsky, Y., Franklin, L. S., \& Bagayoko, D. (2018). First-principles studies of electronic, transport and bulk properties of pyrite $\mathrm{FeS}_{2}$. AIP Advances, 8(2), 25212. https://doi.org/10.1063/1.4996551

Bi, Y., Yuan, Y., Exstrom, C. L., Darveau, S. A., \& Huang, J. (2011). Air Stable , Photosensitive , Phase Pure Iron Pyrite Nanocrystal Thin. Nano Letters, 11(1) 4953-4957.

Botchway, E. A., Ampong, F. K., Nkrumah, I., Boakye, F. K., \& Nkum, R. K. (2019). Growth of a Pure and Single Phase Iron Sulfide (Pyrite) Thin Film by Electrochemical Deposition for Photovoltaic Applications. Open Journal of Applied Sciences, 9(9), 725-735

Cabán-Acevedo, M., Faber, M. S., Tan, Y., Hamers, R. J., \& Jin, S. (2012). Synthesis and properties of semiconducting iron pyrite $\left(\mathrm{FeS}_{2}\right)$ nanowires. Nano Letters, 12(4), 1977-1982.

Clayton, A. J., Irvine, S. J. C., Barrioz, V., Brooks, W. S. M., Zoppi, G., Forbes, I., Rogers, K. D., Lane, D. W., Hutchings, K., \& Roncallo, S. (2011). Metalorganic chemical vapor deposition of ultra-thin photovoltaic devices using a pyrite based $\mathrm{p}-\mathrm{i}-\mathrm{n}$ structure. Thin Solid Films, 519(21), 7360-7363. https://doi.org/https://doi.org/10.1016/j.tsf.2010.1 2.147

Ezema, F. I., \& Ph, D. (2005). Chemical Bath Deposition of Bismuth Chloride Oxide ( $\mathrm{BiClO}$ ) Thin Film and its Applications $\alpha=\mathrm{A}(\alpha \mathrm{h} v-\mathrm{Eg}) \mathrm{R}=(\mathrm{n}-1)$. The Pacific Journal of Science and Technology, 6(1), $6-15$.

Hodes, G. (2002). Chemical solution deposition of semiconductor films. CRC press.

Hone, F. G., Ampong, F. K., Abza, T., Nkrumah, I., Nkum, R. K., \& Boakye, F. (2015). Investigating the effect of deposition time on the morphology, structure and optical band gap of PbS thin films synthesized by CBD technique. Elixir Thin Film Tech., 76, 2843228437.

Hone, F. G., Ampong, F. K., Abza, T., Nkrumah, I., Paal, M., Nkum, R. K., \& Boakye, F. (2015). The effect of deposition time on the structural, morphological and optical band gap of lead selenide thin films synthesized by chemical bath deposition method. Materials Letters, 155(155), 58-61. https://doi.org/10.1016/j.matlet.2015.04.074

Hone, F. G., Ampong, F. K., Nkrumah, I., Nkum, R. K., \& Boakye, F. (2015). Effect of deposition temperature on the structural, morphological and optical band gap of lead selenide thin films synthesized by chemical bath deposition method. Elixir Thin Film Technology, 183,320-325. https://doi.org/10.1016/j.matchemphys.2016.08.0 34
Liu, S., Wu, J., Yu, P., Ding, Q., Zhou, Z., Li, H., Lai, C., Chueh, Y.-L., \& Wang, Z. M. (2014). Phase-pure iron pyrite nanocrystals for low cost .photodetectors..Nanosc ale Research Letters, 9(1), 549. https://doi.org/10.1186/1556-276X-9-549

Mazón-Montijo, D. A., Nair, M. T. S., \& Nair, P. K. (2013). Iron Pyrite Thin Films via Thermal Treatment of Chemically Deposited Precursor Films. ECS Journal of Solid State Science and Technology, 2(11),

P465-P470. https://doi.org/10.1149/2.028311jss

Moon, D. G., Rehan, S., Lim, S. Y., Nam, D., Seo, I., Gwak, J., Cheong, H., Cho, Y. S., Lee, Y., \& Ahn, S. (2018). Structural, optical and electrical impacts of marcasite in pyrite thin films. Solar Energy, 159, 930-939. https://doi.org/https://doi.org/10.1016/j.solener.20 17.11 .026

Muniz, F. T. L., Miranda, M. A. R., dos Santos, C., \& Sasaki, J. M. (2016). The Scherrer equation and the dynamical theory of X-ray diffraction. Acta Crystallographica Section A, 72(3), 385-390. https://doi.org/10.1107/S205327331600365X

Ngbiche, D. U., Nkrumah, I., Ampong, F. K., Paal, M., Nkum, R. K., \& Boakye, F. K. (2019). Optical and Structural Properties of Chemical Bath Deposited Cadmium Sulphur Selenide (CdS1-xSex $(0 \leq \mathrm{x} \leq$ 1)) Thin Films. Open Journal of Applied Sciences, 09(11), https://doi.org/10.4236/ojapps.2019.911064 785-798. ., Pawar, B. S., \& Kim, J. H. (2011). Oh-Shim Joo, CD Lokhande. Recent status of chemical bath deposited metal chalcogenide and metal oxide thin films. Current Applied Physics, 11(2), 117-161.

Prabukanthan, P., Soukup, R. J., Ianno, N. J., Sarkar, A., Kment, Š., Kmentova, H., Kamler, C. A., Exstrom, C. L., Olejníček, J., \& Darveau, S. A. (2010). Chemical bath deposition (CBD) of iron sulfide thin films for photovoltaic applications, crystallographic and optical properties. 201035 th IEEE Photovoltaic Specialists Conference, 29652969. https://doi.org/10.1109/PVSC.2010.5614465

Richardson, B. J., Zhu, L., \& Yu, Q. (2013). Inverted hybrid solar cells based on pyrite $\mathrm{FeS}_{2}$ nanocrystals in P3HT:PCBM with enhanced photocurrent and airstability. Solar Energy Materials and Solar Cells, 116 , 252-261. https://doi.org/https://doi.org/10.1016/j.solmat.20 13.05.014

Saeed Akhtar, M., Alenad, A., \& Azad Malik, M. (2015). Synthesis of mackinawite FeS thin films from acidic chemical baths. Materials Science in Semiconductor Processing, 32, 1-5. https://doi.org/https://doi.org/10.1016/j.mssp.2014 .12 .073

Wadia, C., Wu, Y., Gul, S., Volkman, S. K., Guo, J., \& Alivisatos, A. P. (2009). Surfactant-Assisted Hydrothermal Synthesis of Single phase Pyrite $\mathrm{FeS}_{2}$ Nanocrystals. Chemistry of Materials, 21(13),2568-2570. https://doi.org/10.1021/cm901273v

Wang, X., Wang, G., Chen, J., Zhu, X., Tian, J., Jiang, C., Zhang, Y., Liu, X., \& Wang, R. (2013). Pyrite thin films prepared for thermal batteries via sulfuring electrodeposited iron sulfide films: Structure and physical properties. Materials.Letters, 110, 144147. https://doi.org/https://doi.org/10.1016/j.matlet.201 
3.07.107

Zhao, P., Cui, H., Luan, J., Guo, Z., Zhou, Y., \& Xue, H. (2017). Porous $\mathrm{FeS}_{2}$ nanoparticles wrapped by reduced graphene oxide as high-performance
Lithium-ion battery cathodes. Materials Letters, 186, 62-65.

https://doi.org/https://doi.org/10.1016/j.matlet.201 6.09.074 